\title{
Effects of tree age and waterlogging duration on the form factors of eastern cottonwood (Populus deltoides Bartr. ex Marsh.)
}

\section{Zheng Song}

Song, Z. 2019. Effects of tree age and waterlogging duration on the form factors of eastern cottonwood (Populus deltoides Bartr. ex Marsh.). - Forestry Studies | Metsanduslikud Uurimused 70, 58-67, ISSN 1406-9954. Journal homepage: http:// mi.emu.ee/forestry.studies

\begin{abstract}
Stem form is the short name of the tree trunk shape. Stem form determines the quantity and quality of trunk volume, and affects forest timber volume and stand merchantable volume. Based on Populus deltoides Bartr. ex Marsh. in the Dongting Lake region of Hunan Province in China, changes in the breast-height form factor $\left(f_{13}\right)$ and experimental form factor $\left(f_{\mathrm{a}}\right)$ under different waterlogging durations and stand ages were analyzed using the two-way analysis of variance (ANOVA). The results showed that the differences in waterlogging duration for $f_{1.3}$ were not significant, but were significant for $f_{\mathrm{a}}$. Tree age has significant effects on $f_{1.3}$ and $f_{\mathrm{a}}$. In addition, the $f_{\mathrm{a}}$ of $P$. deltoides grown in stands with a waterlogging duration of 24 days and 33 days were slightly larger than the other three 50, 64, 86 days, which indicated that trees grown in these stands (24, 33 days) had larger tree volumes. In addition, the waterlogging duration of longer than 86 days was not suitable for the growth of $P$. deltoides.
\end{abstract}

Key words: stem form, breast-height form factor, experimental form factor.

Author's address: Research Institute of Forestry Policy and Information, Chinese Academy of Forestry, 100091 Beijing, China. *e-mail: songzheng556@163.com

\section{Introduction}

Poplar trees (Populus spp.) are resilient, water-tolerant, wind-resistant, and adapted to growth in a wide range of areas. They have been introduced and planted in alluvial plains, river networks, and near the lakes south of the Yangtze River. Poplar trees are suitable for afforestation and greening in farmlands, river networks, and near the reservoirs of the Yellow and Yangtze River basins where they protect soils from the wind and wave erosion. Hence, poplar trees are one of the major tree species used for afforestation in China (Liu \& Wang, 2009). Populus deltoides Bartr. ex Marsh. is one of the most rapidly growing poplar tree species introduced in China in the last century. This species has characteristics such as rapid growth, superior quality, high production, and water resistance, enabling it to be the preferred tree species for afforestation for seasonally waterlogged beaches in lake regions, protective embankments, and restored lake regions. In addition, the timber of this very adaptable tree can be used in many ways. For quite some time the selective breed- 
ing and cultivation of superior $P$. deltoides clones has attracted the attention of many researchers in China (Pan et al., 1992; Cao et al., 1994; Tong et al., 2002; Liu et al., 2006; $\mathrm{Xu}$ et al., 2011). This has resulted in rapid large-scale afforestation in wetlands in southern China. However, a waterlogged environment may affect the growth of poplar trees.

Cheng (1995) explored changes in tree height and growth in diameter at breast height in poplar trees before and after waterlogging. He found that when waterlogging lasts for less than three months and the height of floodwaters is less than $3 \mathrm{~m}$ this does not affect the survival of poplar trees used for afforestation, but these conditions affect tree growth. Wang (1993) carried out a study on differences in water resistance between poplar clones and determined which poplar species show superior resistance to waterlogging. Liu et al. (1993) conducted a study on cultivating seedlings of poplar clones under waterlogging stress. Gao et al. (2000) conducted a study on poplar physiology and ecology on beaches and pointed out that terrain elevation has significant effects on photosynthesis in poplar trees under waterlogging stress. Kozlowski \& Pallardy (1997) and Lambers et al. (2008) examined the effects of waterlogging stress on tree growth. They pointed out that waterlogging not only affects tree growth in the current year but also affects tree growth in the following year. Wu \& Tang (2002) conducted a study on the effects of waterlogging stress on poplar growth on beaches. He pointed out that the dominant factor affecting poplar afforestation in beaches is the average number of days with waterlogging in a year. The growth of the southern type of $P$. deltoides along the beach wetlands of Dongting Lake decreased with an increased duration of annual mean waterlogging while waterlogging resistance in poplar trees increases with stand age. In recent years, although some progress has been made in forest timber growth in response to waterlogging stress (Zhang et al., 1999; Liu et al., 2006), a unified understanding of the specific mechanisms by which waterlogging affects forests is still lacking. Studies have shown that waterlogging inhibits the growth of many plants and the height growth of $P$. deltoides decreases under waterlogging stress (Yamamoto, 1992; Tang et al., 1998; Jin et al., 2011).

Stem form can serve as an important factor that is often measured in trees because it determines the quantity and quality of timber volume and its variation directly affects both trunk timber volume as well as the total volume of timber produced (Zhong et al., 2002). The effects of genotype, age, branching, and other intrinsic factors can affect differences in stem form. Moreover, environmental differences can affect stem form, such as site condition, climatic factors, terrain and geomorphology, stand density, and management measures. The stem form factor is important for determining the stem form structure of trees. Research on the effects of waterlogging duration on the stem form factor of poplar trees during waterlogging has considerable importance for cultivating poplar trees in this region and for improving the quality of stem form and timber volume of poplar trees. Therefore, in this paper, poplar trees in the Dongting Lake region of Hunan Province, China, were used as the study subject. We studied the changes in the stem form factor under different durations of waterlogging and stem form structural variation patterns in order to identify what type of waterlogged environment is suitable for poplar tree growth.

\section{Study sites}

Dongting Lake, located in northern Hunan Province on the south bank of the Yangtze River, $\left(28-29^{\circ} \mathrm{N}, 110-113^{\circ} \mathrm{E}\right)$ features a subtropical climate with abundant rainfall and sunshine where rainfall and relatively high humidity occurs during the same 
season. The thick soil layer in this region contains abundant amounts of organic matter and minerals, making it extremely suitable for the growth of southern black poplar that originated in the Yunmen swamp (Li, 2000). Dongting Lake has an area of $18,780 \mathrm{~km}^{2}$, of which $15,200 \mathrm{~km}^{2}$ lies within Hunan Province. Dongting Lake, China's second largest lake, collects water from the Xiangjiang, Zijiang, Yuanjiang, and Lishui rivers, while some floodwater from the Yangtze River backs into Dongting Lake during the flood season. The Dongting Lake watershed serves as an important production base for food, cotton, oil, hemp, and fish in China and provides major ecological service functions in regulating floodwaters, reducing pollution, and regulating the climate (Xie \& Chen, 2008; Du et al., 2009). Variations in the water levels and relationships between Dongting Lake and floodwaters from the Ching River have resulted in changes in the amount of water and sediment entering the lake. These changes in Dongting Lake have been caused by both natural and human factors. Every year, around $100 \mathrm{Mt}$ of sediment are deposited at the bottom of the lake, ultimately forming a large area of fertile beaches. The beaches of Dongting Lake resulted from sedimentation from the Yangtze River and the four tributary rivers. An average of $1.4 \times 10^{8} \mathrm{~m}^{3}$ of sediment is deposited annually in the lake (Xiao, 1996). The area with different types of beaches in the Dongting Lake region in Hunan Province covers 222,000 ha. In addition, the beach area of the lake shows a significantly increasing trend at a rate of 45 $\mathrm{km}^{2}$ a year ${ }^{-1}$ (Li \& Deng, 1993; Xiao, 1996).

\section{Material and Methods}

All materials used in this study were obtained from the southeast beach of the $\mathrm{Yu}$ anjiang River along the shores of Dongting Lake in Hunan Province, China. The experimental forest site covered a slope length of
$550 \mathrm{~m}$ with a single-sided gentle slope. The elevation varied by only $2.7 \mathrm{~m}$ and had a slope ratio of $4.9 \%$ in the study area.

The site was afforested with a mix of poplar clones planted in a grid pattern of $6 \mathrm{~m} \times 8 \mathrm{~m}$. In order to examine the effects of variations in waterlogging duration on the suitability of the beach for tree cultivation and to analyze the stem form structure of poplar trees, we set up permanent plots based on elevation differences of $0.5 \mathrm{~m}$ in the experimental forest on the southeastern lake beach. Hydrological observation data from major hydrological stations collected during flood seasons in large lake beach areas with poplar trees were used in this study. We found that the sampling plots with different elevations experienced an annual average of five waterlogging durations $t$, namely $24,33,50,64$, and 86 days. There are eight tree ages (1-8 years) in each treatment of waterlogging duration.

We selected 3-5 average trees from stands by each age and for these selected trees measured the tree height and diameter at breast height before cutting down (Table 1). And a total of about 135 trees were cut down. The mean cross-sectional quadrature was used to obtain the timber volume $v$. The breast height form factor $\left(f_{1.3}\right)$ and experimental form factor $\left(f_{a}\right)$ were used as markers for stem form. Lin (1974) found that the experimental form factor was the other form factor which is a convenient measurement and used for calculating tree volume (Zheng et al., 1997; Zhu et al., 2018). The calculation equations for these two factors are as follows:

$$
\begin{gathered}
f_{1.3}=v /\left(g_{1.3} * h\right) \\
f_{a}=v /\left[g_{a} *(h+3)\right]
\end{gathered}
$$

Where $g_{1.3}=$ tree basal area, $h=$ tree height, $v=$ tree volume.

Next, we conducted a two-way analysis of variance (ANOVA) of different durations of waterlogging and tree age on breast 
Table 1. Mean values of diameter at breast height and total tree height by age and waterlogging durations.

\begin{tabular}{ccccccccccc}
\hline Age & \multicolumn{4}{c}{ Diameter at breast height $(\mathrm{cm})$} \\
\cline { 2 - 11 } & 24 & 33 & 50 & 64 & 86 & 24 & 33 & 50 & 64 & 86 \\
\hline 1 & 3.30 & 2.89 & 2.75 & 2.49 & 2.67 & 3.94 & 3.16 & 3.39 & 3.46 & 3.56 \\
2 & 7.02 & 6.34 & 5.87 & 5.44 & 4.09 & 6.93 & 5.79 & 5.62 & 5.71 & 4.64 \\
3 & 10.67 & 9.81 & 9.00 & 8.40 & 5.62 & 9.69 & 8.37 & 7.86 & 7.78 & 5.66 \\
4 & 14.24 & 13.27 & 12.13 & 11.36 & 7.27 & 12.24 & 10.89 & 10.09 & 9.67 & 6.62 \\
5 & 17.73 & 16.25 & 15.27 & 14.32 & 9.03 & 14.59 & 13.36 & 12.33 & 11.39 & 7.52 \\
6 & 21.15 & 20.22 & 18.41 & 17.30 & 10.93 & 16.76 & 15.78 & 14.58 & 12.97 & 8.36 \\
7 & 24.49 & 23.70 & 21.55 & 20.27 & 12.98 & 18.76 & 18.14 & 16.82 & 14.42 & 9.16 \\
8 & 27.20 & 26.87 & 25.07 & 23.80 & 16.13 & 20.90 & 20.53 & 19.47 & 17.33 & 11.43 \\
\hline
\end{tabular}

height form factors, and experimental form factors to examine the effects of waterlogging duration on structural changes of stem form in poplar trees near Dongting Lake. The ANOVA analysis and post-hoc multiple comparisons (Duncan method) were performed using SPSS software.

\section{Results}

Effects of tree age and waterlogging duration on stem form factor

Table 2 shows the ANOVA results about the breast height form factor. For tree age: $F=18.031, p<0.001$. It indicated the differences in breast height form factor $f_{1.3}$ between different ages were significant. In contrast, the differences in breast height form factor $f_{1.3}$ between different waterlogging durations were not significant $(p=0.692)$ (Figure 1).

Figure 2 shows the post-hoc results of breast height form factor $\left(f_{1.3}\right)$ between eight ages. It was found that the differences in breast height form factors $\left(f_{1.3}\right)$ between the four different tree ages $(2,6$, 7,8 years) were not significant $(p=0.114)$. The differences in $f_{1.3}$ among the three ages $(2,5,6$ years) were also not significant $(p=0.178)$. Insignificant differences were also observed in $f_{1.3}$ among the three ages $(3,4,5$ years, $p=0.114)$. In contrast, the $f_{1.3}$ in one age (1 year) was significantly larger than $f_{1.3}$ in the other 7 ages (Figure 2).

Table 2. Results of analysis of variance on the effects of waterlogging duration $t$ and tree age on the form factors $f_{1.3^{\prime}}$ and $f_{\mathrm{a}}$.

\begin{tabular}{lcccc}
\hline \multirow{2}{*}{ Variables } & \multicolumn{2}{c}{$f_{1.3}$} & \multicolumn{2}{c}{$f_{a}$} \\
\cline { 2 - 5 } & $F$ & $p$-value & $F$ & $p$-value \\
\hline Tree age & 18.031 & $<0.001$ & 12.232 & $<0.001$ \\
$t$ & 0.562 & 0.692 & 3.996 & 0.011 \\
\hline
\end{tabular}

In terms of post-hoc results of the experimental form factors $f_{\mathrm{a}}$ by waterlogging durations, there were no significant differences among the five durations (Figure 3, $p=0.783)$.

Effects of tree ages and waterlogging durations on the experimental form factor From Table 2, we found the ANOVA results about the experimental form factor $f_{\text {a }}$. For tree age: $F=12.232, p<0.001$. It showed that the differences in the experimental form factor $f_{\mathrm{a}}$ between different tree ages were significant. For waterlogging duration $t: F=3.996, p=0.011$. It also indicated that the differences in the experimental form factor $f_{\mathrm{a}}$ between different durations of waterlogging were significant (Figure 1).

In addition, it was found that no significant differences existed in the experimental 

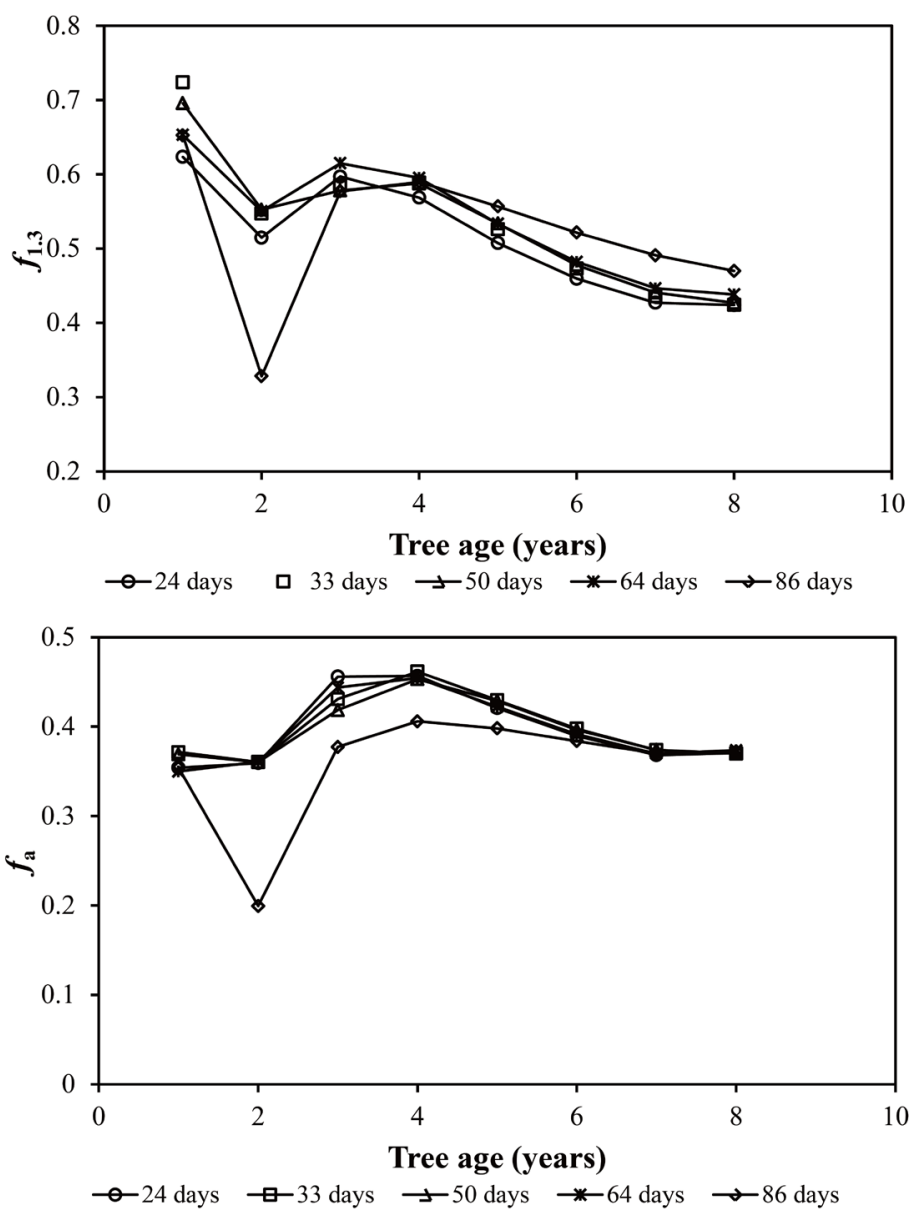

Figure 1. $f_{\mathrm{a}}$ and $f_{1.3}$ for Populus deltoides against tree age.

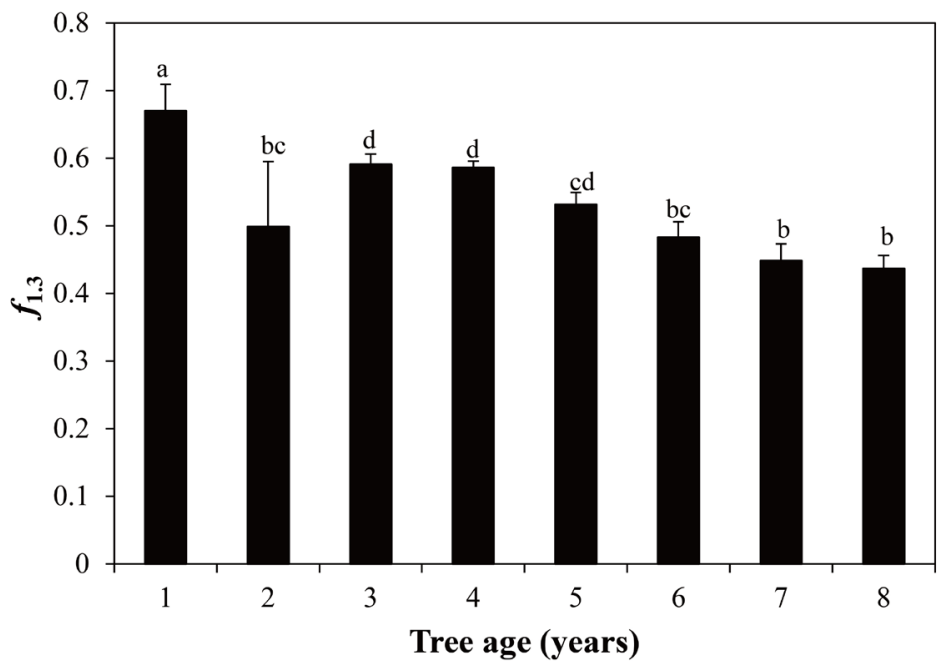

Figure 2. Post hoc multiple comparisons of $f_{1.3}$ by tree ages (the same letter means they are not significant at level 0.05). 


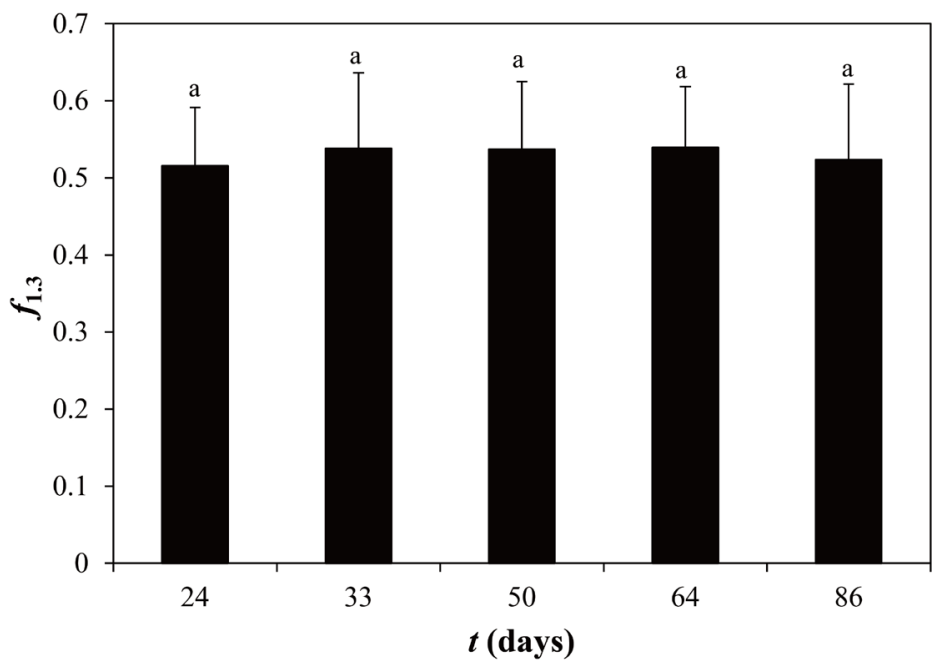

Figure 3. Post hoc multiple comparisons of $f_{1.3}$ by waterlogging durations $(t)$.

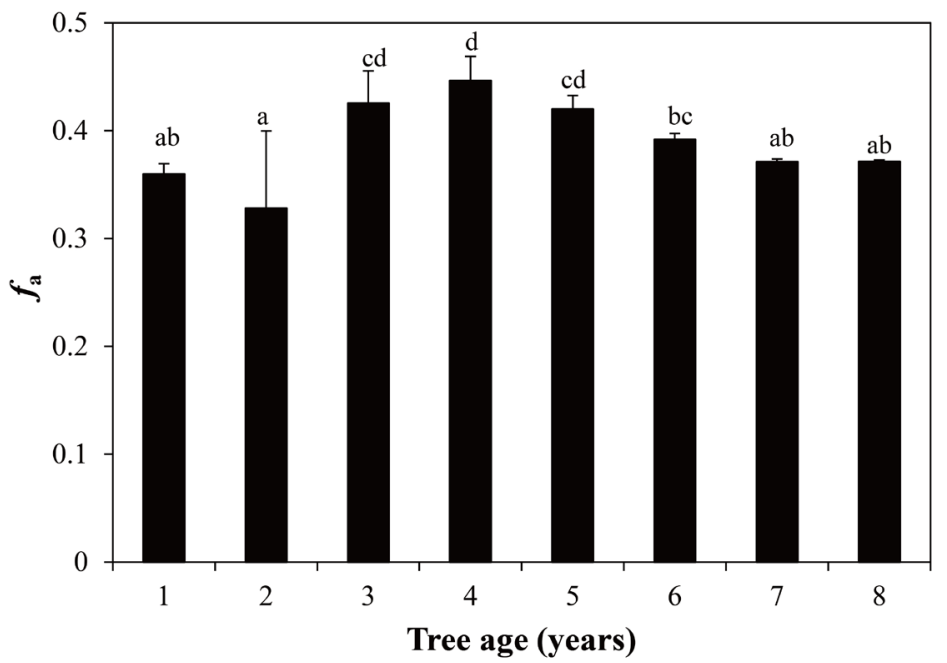

Figure 4. Post hoc multiple comparisons of $f_{\mathrm{a}}$ by tree ages.

form factors $f_{\mathrm{a}}$ between these four tree ages $(1,2,7,8$ years, $p>0.05)$ (Figure 4$)$, which also indicated that the differences were not significant among the four ages $(1,6,7,8$ years, $p=0.202$ ) or among the two different groups of three ages $(3,5,6$ years, $p=0.107)$ and $(3,4,5$ years, $p=0.237)$ (Figure 4$)$.

There were also insignificant differences in $f_{\mathrm{a}}$ between the four waterlogging durations $(24,33,50$, and 64 days, $p=0.991)$. In contrast, $f_{\mathrm{a}}$ in waterlogging durations for 86 days were significantly smaller than those in the other shorter durations $(p<$ 0.05 , Figure 5). It indicated that when the durations were smaller than 86 days, the stem form remained relatively stable and the timber volume of trees planted in the areas with a short duration of waterlogging was relatively large. In other words, it could be concluded that afforestation with poplar was not successful with waterlogging lasting 86 days. 


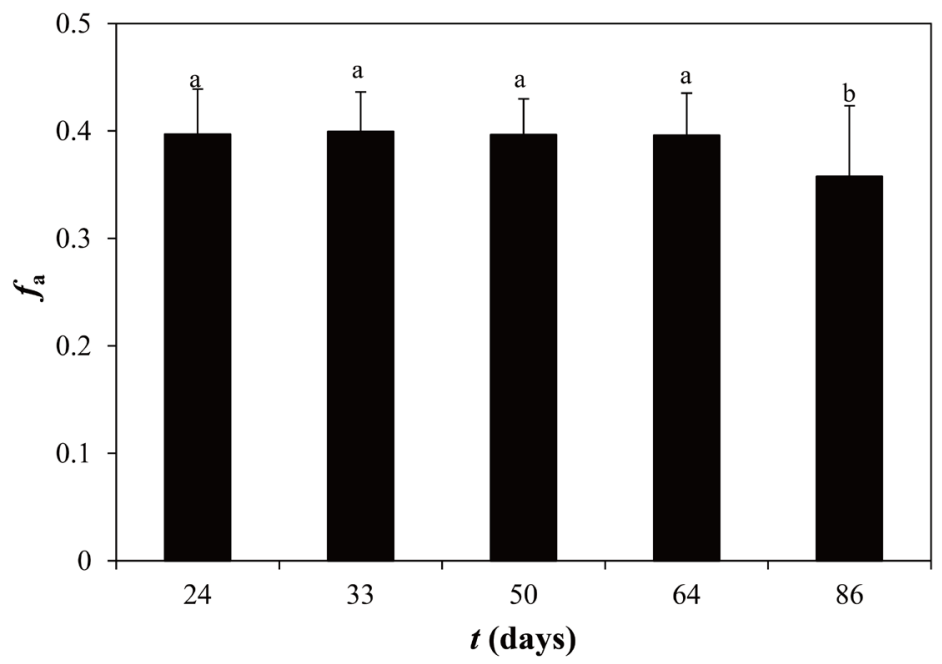

Figure 5. Post hoc multiple comparisons of $f_{\mathrm{a}}$ by waterlogging durations $(t)$.

\section{Discussion}

Tree volume is commonly calculated from the diameter at breast height, height and a form factor $(f)$, which may be seen as a reduction factor of a cylinder (with diameter at breast height and height) to the actual form of the tree (Akindele \& LeMay, 2006; Adekunle, 2007). As we know, form factor is an important component for estimating tree volume (Pollanschütz, 1965; Colgan et al., 2014) as tree forms differ due to site conditions (Bi \& Turner, 1994), different planting densities and forest management practices (Ferreira, 1997; Ikonen et al., 2006), provenance factors (Socha \& Kulej, 2007), and stand age (Avery \& Burkhart, 2002). Ferreira et al. (1997) reported that the form factor values decreased with increasing the spacing for Eucalyptus spp. (more cylindrical trunk in high-density stands). Balloni \& Simoes (1980) also found that the form factor of Pinus patula Schiede ex Schltdl. \& Cham. decreased as the spacing increased. This change reflected an increase of almost $10 \%$ in real volume, highlighting the importance of evaluating such a feature in the study of vital space. The form factor has high importance in the final uses of the wood, where more tapered logs generate a smaller quantity of processed wood for any minimum diameter use in any country. Figueiredo et al. (2005) presented that the form factor had a closer relationship to the cylindrical shape in younger trees, whereas in older trees the conicity is higher. The tree stem taper is the relative rate of change in tree diameter with increasing height (West, 2009; Burkhart \& Tomé, 2012), which could be described by the breast height form factor $\left(f_{1.3}\right)$. However, the experimental form factor $\left(f_{\mathrm{a}}\right)$ was not affected by tree height (Forslund, 1982).

In this study, the analyses of the form factors of $P$. deltoides, described by the experimental form factor $\left(f_{a}\right)$ and breast height form factor $\left(f_{1.3}\right)$, showed that the influences of tree age and waterlogged time on $f_{1.3}$ are not significant at level 0.05 , but significant for $f_{a}$. Tree height of $P$. deltoides decreased due to waterlog (Tang et al., 1998; Jin et al., 2011) and thus affected the tree form. Conner (1994) found that both tree diameter and height of bald cypress (Taxodium distichum (L.) Rich.) and Chinese tallow (Triadica sebifera L.) Small) seedlings were affected by waterlogging. Several researches reported that trees are heterogeneous in structures along waterlogging 
gradients (e.g., Smith-III, 1992; Duke et al., 1998; Sherman et al., 2003), as well as in forest productivity. Liu et al. (2006) found that the waterlogging depth had significant effects on the growth and stem from structure of Taxodium ascendens Brongn. In summary, we found that the tree stem form of $P$. deltoides changed insignificantly at level 0.05 when the waterlogging duration was less than 86 days. However, when waterlogging duration was longer than 86 days, the tree stem form changed significantly at level 0.05 . It indicated that the waterlogging duration of longer than 86 days was not suitable for the $P$. deltoides growth. In addition, the experimental form factors $f_{\text {a }}$ of $P$. deltoides grown in the stands with waterlogging duration of 24 days and 33 days were slightly larger than the other three periods of 50, 64, 86 days, which indicated that trees grown in these stands $(24,33$ days) had larger tree volumes.

\section{Conclusions}

This study analyzed the effects of tree age and the duration of waterlogging on changes in stem form factors of $P$. deltoides trees in the Dongting Lake region and obtained the following conclusions:

- Different durations of waterlogging do not have significant effects on breast height form factors in poplar trees but do have significant effects on experimental form factors. Tree height has some effects on the breast height form factor but not on the experimental form factor. Therefore, the differences in experimental form factors showed that different durations of waterlogging affect changes in stem form structure in poplar trees in this region. In addition, tree age has significant effects on breast height form and experimental form factors.

- When $P$. deltoides were used for afforestation along the beaches of Dongting
Lake, no significant differences in experimental form factors of poplar trees were observed under flowing water and within an annual mean waterlogging duration of 86 days, i.e., stem form remains relatively stable and the trees can be used for afforestation. However, when the annual mean waterlogging duration exceeds 86 days, the variation in experimental form factor changes is larger and stem form becomes unstable, making the sites unsuitable for poplar afforestation.

\section{References}

Adekunle, V.A.J. 2007. Non-linear regression models for timber volume estimation in natural forest ecosystem, Southwest Nigeria. Research Journal of Forestry, 1(2), 40-54.

Akindele, S.O., LeMay, V.M. 2006. Development of tree volume equations for common timber species in the tropical rain forest area of Nigeria. - Forest Ecology and Management, 226(1-3), 41-48.

Avery, T.E., Burkhart, H.E. 2002. Forest Measurements. New York (USA), McGraw Hill Higher Education. 480 pp.

Balloni, E.A., Simoes, J.W. 1980. Planting spacing and its effects on forests. (O espaçamento de plantio e suas implicações silviculturais). IPEF, 1(3), 1-16.

Bi, H., Turner, J. 1994. Long-term effects of superphosphate fertilization on stem form, taper and stem volume estimation of Pinus radiata. - Forest Ecology and Management, 70(1-3), 285-297.

Burkhart, H.E., Tomé, M. 2012. Modeling Forest Trees and Stands. Dordrecht, Springer. 457 pp.

Cao, F., Fang, S., Lu, S., Xu, X., Tang, L. 1994. Principles and practice of intensive culture for Populus clone. - Journal of Nanjing Forestry University, 18(3), 77-81.

Cheng, Z.1995. Studies on flooded influences on growth of Poplar trees in the flat land along Changiiang river in Anhui. - Wang, S.J. (ed.). The Study Progress on Poplar Tree. City, China Forestry Publishing House, 284-289.

Colgan, M.S., Swemmer, T., Asner, G.P. 2014. Structural relationships between form factor, wood density, and biomass in African savanna woodlands. - Trees, 28, 91-102.

Conner, W.H. 1994. The effect of salinity and waterlogging on growth and survival of baldcypress and Chinese tallow seedlings. Journal of Coastal Research, 10, 1045-1049. 
Du, G., Li, S., Zheng, J., Wang, L., Zheng, Y. 2009. Study on spatial distribution and correlation of soil organic matter in wetland of Dongting lake floodplain. - Modern Agricultural Sciences, 16(2), 21-23.

Duke, N.C., Ball, M.C., Ellison, J.C. 1998. Factors influencing biodiversity and distributional gradients in mangroves. - Glob Ecolology and Biogeography Letters, 7, 27-47.

Ferreira, G.W. 1997. Quality of Eucalyptus dunnii Maiden kraft-anthraquinone cellulose planted in five spacings in relation to Eucalyptus grandis Hill ex Maiden and Eucalyptus saligna Smith. (Qualidade da celulose kraft-antraquinona de Eucalyptus dunnii Maiden plantado em cinco espaçamentos em relação ao Eucalyptus grandis Hill ex Maiden e Eucalyptus saligna Smith). Master thesis. Santa Maria, Federal University of Santa Maria. 128 pp.

Figueiredo, E.O., Scolforo, J.R.S., Oliveira, A.D. 2005. Estimation of bark percentage and shape factor in young Teak stands (Tectona grandis L.f). (Estimativa do percentual de casca e do fator de forma em povoamentos jovens de Teca (Tectona grandis L.f)). - Communicado Técnico, 165, 1-5.

Forslund, R.R. 1982. A geometrical tree volume model based on the location of the centre of gravity of the bole. - Canadian Journal of Forest Research, 12(12), 215-221.

Gao, J., Wu, M., Peng, Z. 2000. Study on photosynthesis and physiological ecology of poplar in shoals. - Forest Research, 13(2), 147-152.

Ikonen, V.-P., Kellomäki, S., Väisänen, H., Peltola, H. 2006. Modelling the distribution of diameter growth along the stem in scots pine. - Trees, 20(3), 391-402.

Jin, J., Chen, Q., Zhu.F. 2011. Study on growth and physiological changes of silverwood after flooding. - Journal of Hebei Agricultural Sciences, 15(6), 25-26. (In Chinese with English Abstract).

Kozlowski., T.T., Pallardy, S.G. 1997. Growth Control in Woody plants. San Diego, Academic press. 641 pp.

Lambers, H., Chapin III, F.S., Pons, T.L. 2008. Plant physiological Ecology. New York, SpringerVerlag. 540 pp.

Li, C. 2000. Conceptual model of environmental system evolution of river basin: Interaction between mountains, rivers, lakes and seas and sensitive response to global changes. - Chinese Journal of Mechanical Engineering, 9(3), 358362. (In Chinese with English Abstract).

Li, J., Deng, M. 1993. Dongting lake beach reclamation and its impact on the ecological environment. - Chinese Journal of Mechanical Engineering, 2(4), 340-346. (In Chinese with English Abstract).

Lin, C. 1974. About experimental form factor. Forest Resource Management, 2, 11-19. (In Chinese).
Liu, Z., Hu, J., Dai, X. 2006. Preliminary report of nl-80351 good clone of American black poplar. - Hubei Forestry Science and Technology, (6), 29-31. (In Chinese with English Abstract).

Liu, J., Liu, Y., Wang, S. 1993.The effect of water stress on the net photosynthesis rate of six Poplar clones. - Forest Research, 6(1), 65-69. (In Chinese with English Abstract).

Liu, D., Wang, H. 2009. A brief discussion on the current situation and prospects of poplar short rotation period management. - Heilongjiang Technical Information, (27), 152. (In Chinese with English Abstract).

Liu, G., Zhang, Z., Cui, H., Chen, Y., Zhang, Z., Du, K., Zhu, Q. 2006. Effect of waterlogging depth on trunk morphological structure and growth of Taxodium ascendens. - Journal of Northeast Forestry University, 34(4), 22-23. (In Chinese with English Abstract).

Pan, H.X., Huang, M.R., Ruan, X.G. 1992. Study on wood density characteristics of new clones of American black poplar and young Populus. Forestry Science, 34(1), 73-80. (In Chinese with English Abstract).

Pollanschütz, J. 1965. A new method of determining stem form factor of standing trees. - Presented at the Advisory Group of Forest Statisticians of the International Union of Forest Research Organizations, Section 25, 7-17.

Sherman, R.E., Fahey, T.J., Martinez, P. 2003. Spatial patterns of biomass and aboveground net primary productivity in a mangrove ecosystem in the Dominican Republic. Ecosystems, 6, 384-398.

Smith-III, T.J. 1992. Forest structure. - Robertson A.I., Alongi D.M. (eds.). Tropical Mangrove Ecosystems. Washington DC, American Geological Union, 101-136.

Socha, J., Kulej, M. 2007. Variation of the tree form factor and taper in European larch of Polish provenances tested under conditions of the Beskid Sądecki mountain range (southern Poland). - Journal of Forest Science, 53, 538547.

Tang, L., Xu, X., Fang, S. 1998. Effects of soil waterlogging on growth and physiological characteristics of poplar and willow seedling. - Chinese Journal of Applied Ecology, 9(5), 471-474. (In Chinese with English Abstract).

Tong, Z., Yu, Y., Zheng, Y. 2002. Study on physical and mechanical properties of black yangpai new clonal wood. - Forest Research, 15(4), 450-456. (In Chinese with English Abstract).

Wang, B.S. 1993. Study on the difference of water resistance of new clones of poplar. - Jiangsu Forestry Science and Technology, (4), 1-4. (In Chinese with English Abstract).

West, P.W. 2009. Tree and Forest Measurement. Dordrect, Springer. 190 pp.

Wu, L., Tang, Y. 2002. Study on variation of water level of Dongting lake and growth regularity and growth prediction of poplar in tidal flat. - Hunan Academy of Forestry Sciences, 100116. (In Chinese with English Abstract). 
Xiao, Z. 1996. Ecological environment disaster and development trend in Hunan province. - Chinese Journal of Ecology, 15(1), 51-56. (In Chinese with English Abstract).

Xie, Y., Chen, X. 2008. Effects of three gorges project on vegetation succession in Dongting lake wetland. - Research of Agricultural Modernization, 11(6), 684-687. (In Chinese with English Abstract).

Xu, Y., Weng, W., Zhang, Y. 2011. Differences of wood fiber, duct morphology and basic density in different diameter grades of American black poplar. - Anhui Forestry Science and Technology, 37(1), 2-9. (In Chinese with English Abstract).

Yamamoto, F. 1992. Effects of depth of flooding on growth and anatomy of stems and knee roots of Taxodium distichum. - IAWA Journal, 13(1), 93-104.
Zhang, X., Wu, G., Cai, Q., Peng, Z. 1999. A study of the growth rule of poplar on the seasonal river beaches of Changjiang River. - Journal of Biomathematics, 14(3), 322-326. (In Chinese with English Abstract).

Zheng, X., Liu, D., Liu, Y., Song, X. 1997. Formulae of tree height curve and volume curve derived from theory of column buckling. - Journal of Forestry Research, 8(2), 91-93.

Zhong, Q., Huang, Z., Hu, S. 2002. Analysis of the dry - shaped structure of shavings. - Journal of Jiangxi Agricultural University, 24(2), 233-236. (In Chinese with English Abstract).

Zhu, G., Hu, S., Xiao, Q., Yin, Y. 2018. Comparative analysis of different form factors of Casuarina equisetifolia in Hainan. - Journal of Central South University of Forestry \& Technology, 38(2), 9-15. (In Chinese with English Abstract). 